\title{
Effect of maize replacement with different triticale levels on layers production performance, egg quality, yolk fatty acid profile and blood parameters
}

\author{
C.I. Lim ${ }^{1}$, J. Poaty Ditengou', K.S. Ryu ${ }^{1,4}$, J.H. Kư ${ }^{2}$ M.R. Park², I.M. Whiting ${ }^{3}$ and V. Pirgozliev ${ }^{3}$ \\ 1 Jeonbuk National University, Department of Animal Science, Jeonju 54896, Republic of Korea \\ ${ }^{2}$ National Institute of Crop Science, Central Area Crop Breeding Division, Suwon 16429, Republic of Korea \\ ${ }^{3}$ Harper Adams University, National Institute of Poultry Husbandry, Shropshire TF10 8NB, United Kingdom
}

KEY WORDS: blood analysis, eggs, hens, laying performance, maize substitutes, triticale

Received: 3 September 2021

Revised: 30 November 2021

Accepted: 14 December 2021
${ }^{4}$ Corresponding author: e-mail: seon@jbnu.ac.kr

\begin{abstract}
The study aims to investigate the effect of replacing dietary maize with $0,50,100,150$ and $200 \mathrm{~g} / \mathrm{kg}$ of triticale on production performance, egg quality, yolk fatty acids, and blood variables when fed to laying hens. Five experimental diets were mixed to be isoenergetic and isonitrogenous and were fed to the layers for six weeks, from 22 to 28 week of age. Three hundred and sixty 22-week-old Hy-Line Brown laying hens were individually weighed and randomly allocated to 60 enriched cages giving six birds per cage, in an environmentally controlled experimental house. The cages were equipped with a laying nest, scratching area, metal feeders in front and two nipple drinkers inside. Each diet was fed to 12 cages following randomisation. Feed and water were available ad libitum throughout the experiment. Production variables remained unaffected by the diets containing triticale at various levels. Among the egg quality traits, egg yolk colour linearly decreased $(P<0.001)$ by dietary triticale inclusion. Dietary triticale did not have an impact on egg yolk fatty acid composition $(P>0.05)$. Apart from the glucose level, increasing in a linear fashion $(P<0.001)$ with triticale in diets, the rest of the studied blood variables did not respond $(P>0.05)$ to changes in dietary triticale. It has been concluded that $20 \%$ replacement of maize with triticale in laying hen diets did not have any detrimental impact on egg production variables and or the efficiency of production.
\end{abstract}

\section{Introduction}

Maize is recognised as one of the most efficient energy sources for livestock, particularly within the poultry industry. However, its constantly increasing price due to its demand for feeding both humans and livestock (Bakhtiyary Moez et al., 2020) has led a number of researchers to investigate the use of alternative ingredients with lower production costs and assuring good bird performance. Triticale, a human-made crop resulting from the crossing between wheat and rye, distinguished itself with a low price and a resistance to dry weather compared to maize or wheat. This grain contains also a good protein level that might allow it to fairly replace maize in poultry nutrition. Cornejo et al. (1973) concluded that the triticale sample containing $15.3 \%$ crude protein was equivalent to wheat and maize and superior to barley. If locally produced, triticale may be less expensive and more environmentally friendly cereal to use in animal diets compared to imported cereals. Also, previous experiments indicate that triticale is a good substitute for maize in the diets of broilers (Rao et al., 1976; Reddy et al., 1979) and laying hens (Shafey et al., 1992; Franco et al., 2020). 
When considering laying hens, some scientists investigated the possibility of using triticale in the production of eggs (Fernandez et al., 1973; McNab and Shannon, 1975; Castanon et al., 1990; Çiftci et al., 2003). They found that there was no significant difference in productivity, even when the nutrition of birds was based only on triticale. However, other reports (Leeson and Summers, 1987; Ebrahimi et al., 2017; Bakhtiyary Moez et al., 2020) noticed that higher proportions of triticale grain usage could decrease egg production. The contradiction in these reports shows that more research is needed to study the effects of higher inclusion rates of triticale in diets for laying hens. Moreover, most of the research on triticale in poultry nutrition is done with broilers and only a few papers are focused on laying hen nutrition and the impact on egg production, egg quality and egg yolk fatty acid content. In addition, diets affect blood biochemical variables of poultry (Etim et al., 2014a), but information is lacking on the impact of triticale containing diets on hens blood parameters. Since blood biochemical variables are used to monitor the health of the animals, obtaining such information is of great importance. Therefore, the present experiment aimed to study the effect of maize replacement with different levels of triticale on layering hen production performance, egg quality, yolk fatty acid profile and blood haematology.

\section{Material and methods}

\section{Experimental birds, housing and diets}

Three hundred and sixty 22-week-old Hy-Line Brown laying hens were individually weighed and randomly allocated to 60 enriched cages $(1205 \times$ $50 \mathrm{~cm}$ floor space; $67 \mathrm{~cm}$ height), giving six birds per cage, in an environmentally controlled experimental house. The cages were equipped with a laying nest, scratching area, metal feeders in front and two nipple drinkers inside. Feed and water were available ad libitum throughout the experiment. Each diet was fed to 12 cages following randomisation, from 22 to 28 week of age. The experimental diets presented in Table 1 were isoenergetic (11.72 MJ/kg metabolizable energy $(\mathrm{ME}))$ and isonitrogenous $(17 \%$ crude protein (CP)). To achieve a constant chemical composition of the experimental diets, the ingredients of the diets were used in different proportions. The triticale (cultivar Joseong) used in the diets was obtained from the Central Area Crop Breeding Division of National Institute of Crop Science located in Suwon (Republic of Korea) and was used to replace maize at 5, 10,15 and $20 \%$. The chemical composition of used diets, triticale and maize was determined as described elsewhere (Watts et al., 2021) and is presented in Tables 1 and 2.

Table 1. Approximate chemical composition and ingredients of the experimental diets and as-hatched nutrition specification for Hy-Line Brown laying hens

\begin{tabular}{|c|c|c|c|c|c|}
\hline \multirow{2}{*}{ Indices } & \multicolumn{5}{|c|}{ Dietary triticale groups ${ }^{1}$} \\
\hline & 1 & 2 & 3 & 4 & 5 \\
\hline \multicolumn{6}{|l|}{ Ingredient, g/kg } \\
\hline triticale & - & 50.0 & 100.0 & 150.0 & 200.0 \\
\hline maize & 605.9 & 554.9 & 508.4 & 462.2 & 423.6 \\
\hline soybean meal & 236.7 & 240.4 & 238.1 & 237.5 & 234.0 \\
\hline maize gluten meal & 26.9 & 21.5 & 21.5 & 20.2 & 18.8 \\
\hline wheat bran & - & 7.0 & 6.0 & 5.0 & - \\
\hline beef tallow & 12.0 & 9.6 & 9.6 & 9.0 & 8.4 \\
\hline salt & 2.9 & 2.3 & 2.3 & 2.2 & 2.0 \\
\hline limestone & 93.3 & 94.1 & 94.1 & 94.5 & 94.7 \\
\hline calcium phosphate & 18.8 & 16.7 & 16.5 & 15.9 & 15.0 \\
\hline choline chloride & 0.8 & 0.8 & 0.8 & 0.8 & 0.8 \\
\hline $\begin{array}{l}\text { vitamin-mineral } \\
\text { premix }^{2}\end{array}$ & 2.7 & 2.7 & 2.7 & 2.7 & 2.7 \\
\hline \multicolumn{6}{|l|}{ Calculated values } \\
\hline $\begin{array}{l}\text { metabolic energy, } \\
\mathrm{MJ} / \mathrm{kg}\end{array}$ & 11.72 & 11.72 & 11.72 & 11.72 & 11.72 \\
\hline crude protein, $\mathrm{g} / \mathrm{kg}$ & 170.0 & 170.0 & 170.0 & 170.0 & 170.0 \\
\hline calcium, g/kg & 40.0 & 40.0 & 40.0 & 40.0 & 40.0 \\
\hline $\begin{array}{l}\text { available phospho- } \\
\text { rus, g/kg }\end{array}$ & 3.6 & 3.6 & 3.6 & 3.6 & 3.6 \\
\hline lysine, g/kg & 8.2 & 8.2 & 8.2 & 8.3 & 8.3 \\
\hline methionine, $\mathrm{g} / \mathrm{kg}$ & 3.6 & 3.6 & 3.6 & 3.6 & 3.5 \\
\hline \multicolumn{6}{|l|}{ Determined values } \\
\hline dry mater, g/kg & 874.0 & 877.3 & 879.6 & 876.1 & 873.5 \\
\hline gross energy, MJ/kg & 14.0 & 13.8 & 13.9 & 14.1 & 13.7 \\
\hline crude protein, g/kg & 168.0 & 171.0 & 169.0 & 167.0 & 166.5 \\
\hline calcium, g/kg & 39.3 & 38.5 & 40.5 & 37.4 & 39.8 \\
\hline phosphorus, g/kg & 3.3 & 3.1 & 3.5 & 3.2 & 3.4 \\
\hline
\end{tabular}

1 triticale content in experimental diets: $1-0 \mathrm{~g} / \mathrm{kg}, 2-50 \mathrm{~g} / \mathrm{kg}$, $3-100 \mathrm{~g} / \mathrm{kg}, 4-150 \mathrm{~g} / \mathrm{kg}, 5-200.0 \mathrm{~g} / \mathrm{kg} ;{ }^{2}$ provided per $\mathrm{kg} / \mathrm{feed}$ : $\mu \mathrm{g}$ : retinol 2 160, cholecalciferol 75; mg: a-tocopherol 25, menadione 1.5 , riboflavin 5 , pantotenic acid 8 , cyanocobalamin 0.01 , pyridoxine 1.5 , thiamine 1.5 , folic acid 0.5 , niacin 30 , biotin 0.06 , iodine 0.8 , copper 10 , iron 80 , selenium 0.3 , manganese 80 , zinc 80

\section{Laying hens performance}

The egg number was recorded daily while the egg weight was measured weekly during the experiment. These data were used to determine egg production, feed intake and feed conversion ratio (FCR) for egg production for the entire study period from 22 to 28 week of age. The feed conversion ratio for egg production was calculated as the amount of feed consumed per unit of egg weight at the end of the study after the six-week feeding period. 
Table 2. Experimental triticale and maize chemical composition ${ }^{1}$

\begin{tabular}{lcc}
\hline \multirow{2}{*}{ Indices } & \multicolumn{2}{c}{ Determined values } \\
\cline { 2 - 3 } & triticale & maize \\
\hline Dry matter, g/kg & 883 & 890 \\
Gross energy, MJ/kg & 15.76 & 16.50 \\
Crude protein, g/kg & 97.9 & 83.2 \\
Crude fibre, g/kg & 25.1 & 23.4 \\
Fat, g/kg & 14.8 & 38.7 \\
Ash, g/kg & 17.6 & 11.4 \\
Calcium, g/kg & 0.93 & 0.30 \\
Phosphorus, g/kg & 3.80 & 2.80 \\
\hline
\end{tabular}

${ }^{1}$ triticale was from cultivar Joseong and the maize sample was obtained from the market

\section{Egg quality}

At the end of the study, 60 eggs (each from a different cage, 12 eggs per dietary treatment) from the last day of the study were collected to evaluate egg quality. After one day of storage, albumen height, Haugh unit, egg yolk and eggshell colour, eggshell thickness and eggshell weight were measured by using an egg multitester instrument (QSM-System, TSS, York, UK) as previously described (Pirgozliev et al., 2010; Whiting et al., 2019).

\section{Egg yolk fatty acids}

Concerning egg yolk fatty acid analyses, 25 eggs (5 eggs per dietary treatment) were randomly collected at the end of the experiment. The eggs were then broken into a Petri dish, the fresh yolk was separated from the albumen, well homogenised and used for the analysis. The yolks were analysed for the following fatty acids: saturated fatty acids (SFA): myristic acid (C14:0), palmitic acid (C16:0), stearic acid (C18:0) and arachidic acid (C20:0); monounsaturated fatty acids (MUFA): myristoleic acid (C14:1), oleic acid (C18:1n-9), vaccenic acid (C18:1n-7), paullinic acid (C20:1), eicosadienoic acid (C20:2) (PUFA); and polyunsaturated fatty acids (PUFA): $\alpha$-linoleic acid (C18:3), dihomo- $\gamma$-linolenic acid (C20:3) and docosahexaenoic acid (C22:6).

The fatty acids in each treatment were determined by adding a $4: 1$ solution of methanol and benzene, and $200 \mu \mathrm{l}$ of acetyl chloride to $0.5 \mathrm{~g}$ of egg yolk. The product mixing was heated at $100^{\circ} \mathrm{C}$ for $1 \mathrm{~h}$. After this, $2 \mathrm{ml}$ of $6 \%$ potassium and hexane were added, followed by centrifugation $(3000 \mathrm{rpm}$, $4{ }^{\circ} \mathrm{C}, 15 \mathrm{~min}$ ) to obtain a hexane layer of fatty acids. Helium was used as the test gas and the split ratio was 30:1. The analysis was performed using gas chromatography-mass spectrometry equipment (GC-MS; 6890N-5973, Agilent Technologies, Santa Clara, CA, USA). Peaks were identified by compari- son of retention times with those of the corresponding standards of FAMEmix-37 and FAMEmix-C8C24 (Supelco, Bellefonte, PA, USA). Amounts of fatty acids were expressed as a percentage $(\mathrm{w} / \mathrm{w})$ of total fatty acid methyl esters (FAMEs).

\section{Blood chemical analysis}

At the end of this experiment, blood was collected from 25 hens randomly selected from each dietary treatment ( 5 hens per dietary treatment). The blood samples were obtained from the brachial vein of 28-week-old birds as previously described (Kelly and Alworth, 2013). The collected blood was separated from the serum using a centrifuge $(3000 \mathrm{rpm}$, $4{ }^{\circ} \mathrm{C}, 15 \mathrm{~min}$ ) and stored in a sample cup. After arranging the segment, albumin, aspartate aminotransferase (AST), alanine transferase (ALT), calcium, phosphorus, cholesterol, glucose, total protein and triglyceride were analysed using a full-automatic biochemical analyser (Automatic Biochemical Analyser, Konelab 20, Clinical Diagnostic (part of Thermo Fisher Scientific), Vantaa, Finland).

\section{Statistical analysis}

The observational unit was a cage with six birds. Statistical analyses were performed by GenStat (GenStat, 19 ${ }^{\text {th }}$ Edition, Lawes Agricultural Trust, VSN International Ltd, Oxford, UK). The data were analysed by ANOVA with a random term block and a fixed term treatment. Polynomial contrasts were performed to test for linear (L) and quadratic $(Q)$ relationships between triticale inclusion rate and the variable in question. A protected LSD test was used to separate differences between means if statistical differences were evident $(P<0.05)$ and trends were noted when the $P$-value was about 0.1 .

\section{Results}

The analysed chemical composition of the experimental diets is shown in Table 1 . The protein and $\mathrm{Ca}$ contents were within the expected range. The determined composition of triticale and maize is presented in Table 2. Maize was slightly higher in fat and gross energy although triticale contained slightly more protein, crude fibre and minerals.

Table 3 shows that triticale inclusion in the replacement of maize had no effect on layer performance during the overall period of the experiment $(P>0.05)$. Concerning the egg quality, the main parameters (shell colour, albumen height, Haugh unit, shell thickness, and shell weight) remained unaffected by triticale in the diets (Table 4). However, the yolk colour was progressively re- 
Table 3. Effect of maize replacement with different triticale levels on layers production performance from 22 to 28 week of age

\begin{tabular}{rrllll}
\hline Indices & $\begin{array}{l}\text { Egg production, } \\
\%\end{array}$ & $\begin{array}{l}\text { Egg weight, } \\
\mathrm{g}\end{array}$ & $\begin{array}{l}\text { Feed intake, } \\
\text { g/bird/day }\end{array}$ & $\begin{array}{l}\text { Daily egg } \\
\text { mass, } \mathrm{g}\end{array}$ & $\begin{array}{l}\text { Feed conversion ratio, } \\
\mathrm{kg} / \mathrm{kg}\end{array}$ \\
\hline $\begin{array}{r}\text { \% of maize replacement with triticale } \\
\text { 0 }\end{array}$ & & & & \\
5 & 94.44 & 55.45 & 102.95 & 52.35 & 1.966 \\
10 & 94.11 & 55.61 & 102.32 & 52.34 & 1.956 \\
15 & 95.24 & 55.52 & 104.32 & 52.88 & 1.974 \\
20 & 94.74 & 56.18 & 103.93 & 53.22 & 1.954 \\
SEM & 93.78 & 55.55 & 103.22 & 52.08 & 1.982 \\
P & 0.838 & 0.394 & 0.819 & 0.405 & 0.0152 \\
L & 0.771 & 0.698 & 0.468 & 0.313 & 0.667 \\
Q & 0.797 & 0.546 & 0.419 & 0.795 & 0.547 \\
\hline
\end{tabular}

SEM - standard error of mean, $\mathrm{P}$ - significance between treatments determined by ANOVA, L - linear effects of added dietary triticale activities, $Q$ - quadratic effects of added dietary triticale activities

Table 4. Effect of maize replacement with different triticale levels on egg quality parameters

\begin{tabular}{rllllll}
\hline Indices & $\begin{array}{l}\text { Shell colour, } \\
\mathrm{L}^{*}\end{array}$ & $\begin{array}{l}\text { Albumen height, } \\
\mathrm{mm}\end{array}$ & $\begin{array}{l}\text { Haugh } \\
\text { unit }\end{array}$ & $\begin{array}{l}\text { Yolk colour, } \\
\mathrm{L}^{*}\end{array}$ & $\begin{array}{l}\text { Shell thickness, } \\
\mathrm{mm}\end{array}$ & $\begin{array}{l}\text { Shell weight, } \\
\mathrm{g}\end{array}$ \\
\hline $\begin{aligned} \text { \% of maize replacement with triticale } \\
0\end{aligned}$ & 23.27 & 9.72 & 98.71 & $5.27^{\mathrm{a}}$ & 0.421 & 5.56 \\
5 & 23.40 & 9.97 & 99.79 & $4.87^{\mathrm{b}}$ & 0.416 & 5.55 \\
10 & 22.60 & 9.54 & 97.58 & $4.93^{\mathrm{ab}}$ & 0.435 & 5.84 \\
15 & 24.13 & 9.92 & 99.47 & $4.47^{\mathrm{c}}$ & 0.430 & 5.61 \\
20 & 23.60 & 9.60 & 97.96 & $4.17^{\mathrm{c}}$ & 0.428 & 5.68 \\
SEM & 0.709 & 0.163 & 0.734 & 0.135 & 0.0060 & 0.0952 \\
P & 0.653 & 0.256 & 0.163 & $<0.001$ & 0.201 & 0.196 \\
L & 0.533 & 0.589 & 0.436 & $<0.001$ & 0.141 & 0.305 \\
$\mathrm{Q}$ & 0.707 & 0.609 & 0.700 & 0.509 & 0.422 & 0.318 \\
\hline
\end{tabular}

SEM - standard error of mean, $P$ - significance between treatments determined by ANOVA, $L$ - linear effects of added dietary triticale activities, $Q$ - quadratic effects of added dietary triticale activities; ${ }^{a-c}$ - means in each column with no common superscript are significantly different at $P<0.05$

duced by triticale. Indeed, there was a linear response of yolk colour to triticale in the diets $(P<0.001)$. Overall, the maize replacement with triticale levels of $5,10,15$ and $20 \%$, linearly decreased the control yolk colour by $7.59,6.45$, 15.18 and $20.87 \%$, respectively. The egg yolk fatty acids were not impacted by the different percentages of triticale in the diets, even though a tendency for a quadratic response $(P=0.052)$ was observed for egg yolk C18:3 content for triticale inclusion (Table 5). Except for glucose, the other blood biochemical variables were not significantly influ-

Table 5. Effect of maize replacement with different triticale levels on layers egg yolk fatty acid composition, $\%$

\begin{tabular}{|c|c|c|c|c|c|c|c|c|c|c|c|c|c|c|c|c|}
\hline \multirow{2}{*}{\multicolumn{17}{|c|}{$\begin{array}{l}\text { Indices } \quad \mathrm{C} 14: 0 \quad \mathrm{C} 14: 1 \mathrm{C} 16: 0 \quad \mathrm{C} 18: 0 \\
\% \text { of maize replacement with triticale }\end{array}$}} \\
\hline & & & & & & & & & & & & & & & & \\
\hline 0 & 2.79 & 0.35 & 28.85 & 9.17 & 44.86 & 12.75 & 0.39 & 0.05 & 0.17 & 0.12 & 0.25 & 0.20 & 40.85 & 58.16 & 0.99 & 59.15 \\
\hline 5 & 3.15 & 0.36 & 28.29 & 9.17 & 43.28 & 14.56 & 0.38 & 0.05 & 0.19 & 0.11 & 0.25 & 0.23 & 40.64 & 58.39 & 0.97 & 59.36 \\
\hline 10 & 2.49 & 0.37 & 29.09 & 9.38 & 44.51 & 12.91 & 0.46 & 0.06 & 0.19 & 0.15 & 0.27 & 0.14 & 41.02 & 57.98 & 1.00 & 58.98 \\
\hline 15 & 2.56 & 0.43 & 29.78 & 7.45 & 45.83 & 12.66 & 0.49 & 0.07 & 0.18 & 0.14 & 0.23 & 0.19 & 39.86 & 59.10 & 1.04 & 60.14 \\
\hline 20 & 2.63 & 0.39 & 29.18 & 8.94 & 45.30 & & 0.42 & 0.06 & 0.18 & 0.13 & 0.24 & 0.19 & 40.81 & 58.22 & 0.97 & 59.19 \\
\hline SEM & 0.300 & 0.030 & 0.576 & 0.863 & 1.113 & 1.157 & 0.030 & 0.018 & 0.017 & 0.026 & 0.021 & 0.044 & 0.826 & 0.823 & 0.075 & 0.82 \\
\hline$P$ & 0.426 & 0.502 & 0.494 & 0.526 & 0.574 & 0.692 & 0.086 & 0.716 & 0.934 & 0.845 & 0.634 & 0.707 & 0.873 & 0.890 & 0.963 & 0.873 \\
\hline L & 0.280 & 0.415 & 0.252 & 0.435 & 0.344 & 0.472 & 0.092 & 0.356 & 0.826 & 0.670 & 0.413 & 0.431 & 0.747 & 0.756 & 0.887 & 0.74 \\
\hline$Q$ & 0.876 & 0.884 & 0.930 & 0.794 & 0.607 & 0.520 & 0.174 & 0.647 & 0.461 & 0.553 & 0.564 & 0.558 & 0.801 & 0.826 & 0.917 & 0.80 \\
\hline
\end{tabular}

SEM - standard error of mean, $\mathrm{P}$ - significance between treatments determined by ANOVA, L - linear effects of added dietary triticale activities, $Q$ - quadratic effects of added dietary triticale activities; $\Sigma$ SFA - saturated fatty acids, $\sum$ MUFA - monounsaturated fatty acids, ¿PUFA - polyunsaturated fatty acids, $\Sigma$ UFA - unsaturated fatty acids 
Table 6. Effect of maize replacement with different triticale levels on blood biochemical variables

\begin{tabular}{|c|c|c|c|c|c|c|c|c|c|}
\hline Indices & $\begin{array}{l}\text { Albumin, } \\
\mathrm{mg} / \mathrm{dl}\end{array}$ & $\begin{array}{l}\text { Calcium, } \\
\mathrm{mg} / \mathrm{dl}\end{array}$ & $\begin{array}{l}\text { Phosphorus, } \\
\mathrm{mg} / \mathrm{dl}\end{array}$ & $\begin{array}{l}\text { Cholesterol, } \\
\mathrm{mg} / \mathrm{dl}\end{array}$ & $\begin{array}{l}\text { Glucose, } \\
\mathrm{mg} / \mathrm{dl}\end{array}$ & $\begin{array}{l}\text { AST, } \\
\text { IU/I }\end{array}$ & $\begin{array}{l}\text { ALT, } \\
\text { IU/I }\end{array}$ & $\begin{array}{l}\text { Total protein, } \\
\mathrm{mg} / \mathrm{dl}\end{array}$ & $\begin{array}{l}\text { Triglyceride, } \\
\mathrm{mg} / \mathrm{dl}\end{array}$ \\
\hline \multicolumn{10}{|c|}{$\%$ of maize replacement with triticale } \\
\hline 0 & 1.97 & 26.0 & 5.2 & 116.5 & $197.4^{b}$ & 160.3 & 2.28 & 5.88 & 1490 \\
\hline 5 & 1.89 & 24.1 & 4.4 & 115.4 & $196.8^{b}$ & 152.6 & 1.34 & 5.35 & 1397 \\
\hline 10 & 1.96 & 26.2 & 4.8 & 106.8 & $214.4^{\mathrm{ab}}$ & 172.4 & 1.78 & 5.66 & 1279 \\
\hline 15 & 1.98 & 26.1 & 5.3 & 110.4 & $229.8^{a}$ & 175.8 & 1.77 & 5.85 & 1231 \\
\hline 20 & 1.93 & 25.9 & 5.0 & 126.7 & $226.1^{\mathrm{a}}$ & 173.8 & 2.09 & 5.60 & 1437 \\
\hline SEM & 0.044 & 1.379 & 0.364 & 11.94 & 5.87 & 8.30 & 0.737 & 0.166 & 257.2 \\
\hline P & 0.624 & 0.794 & 0.444 & 0.809 & 0.001 & 0.249 & 0.916 & 0.200 & 0.947 \\
\hline $\mathrm{L}$ & 0.880 & 0.693 & 0.721 & 0.690 & $<0.001$ & 0.070 & 0.978 & 0.904 & 0.743 \\
\hline$Q$ & 0.990 & 0.811 & 0.376 & 0.307 & 0.709 & 0.872 & 0.463 & 0.485 & 0.496 \\
\hline C & 0.142 & 0.357 & 0.102 & 0.601 & 0.058 & 0.226 & 0.656 & 0.025 & 0.736 \\
\hline
\end{tabular}

AST - aspartate aminotransferase, ALT - alanine transaminase, SEM - standard error of mean, $\mathrm{P}$ - significance between treatments determined by ANOVA, $L$ - linear effects of added dietary triticale activities, $Q$ - quadratic effects of added dietary triticale activities; $C$ - significance between the versus all the diets containing triticale determined by comparisons contrast tests; ${ }^{\text {ab }}$ - means in each column with no common superscript are significantly different at $P<0.05$

enced $(P>0.05)$ by triticale incorporation in the diets (Table 6). The blood glucose level linearly increased $(P<0.001)$ with the increase of dietary triticale.

\section{Discussion}

The replacement of maize with various triticale levels did not influence the layer's production performance over the experimental period. These results support those of Hermes and Johnson (2004), suggesting that the inclusion of up to $30 \%$ triticale in layer diets does not significantly influence feed consumption, egg production or egg weight. Moreover, several reports showing the possibility of using triticale for egg production (Fernandez et al., 1973; McNab and Shannon 1975; Castanon et al., 1990; Çiftci et al., 2003; Franco et al., 2020), concluded that there was no difference in productivity, even in the case when the nutrition of hens was based only on triticale. In another experiment by Jamroz et al. (2001), testing the effect of different cereals on laying hen performance, it was reported that the whole replacement of wheat-based diet by triticale as the main energy source had no significant incidence on laying rate, feed conversion ratio or egg mass. However, research with quails (Ebrahimi et al., 2017; Bakhtiyary Moez et al., 2020) showed that replacing wheat or maize with triticale at high proportions (between 50 and 100\%) led to a reduction in feed intake and egg production. Indeed, compared to wheat and maize, triticale contains high amounts of soluble arabinoxylans and total non-starch polysaccharides (NSP), thus its excessive dietary inclusion could reduce feed consumption, nutrient availability and bird performance. Also, compared to laying hens, quail have a smaller and less developed gastrointestinal tract (Hassouna, 2001) that may not be able to process high amounts of dietary NSP, which may further explain the better use of dietary triticale by laying hens.

In addition, the divergences in findings with laying hens could be due to the varying levels of fibre in triticale varieties. Indeed, new varieties of triticale with lower anti-nutritional factors have been grown, improving both its yield and nutritive value (Boros, 1999; Bielski et al., 2015). The triticale used in this experiment was from cultivar Joseong, which is characterised by having a relatively low fibre content $(25.1 \mathrm{~g} / \mathrm{kg})$, which supports the observed lack of changes in productive performance when replacing maize in the diets. From these results, we can advise that triticale can replace up to $20 \%$ of dietary maize in laying hens diet without causing any negative effects on production.

Feed accounts for about $70 \%$ of poultry production cost (Spring, 2013), thus even a small reduction in dietary cost would increase production efficiency. According to Agro-Market24 (2021), the advertised price of maize is $286 \$ / t$ and for triticale $173 \$ / t$. A replacement of $20 \%$ maize with $20 \%$ triticale in the experimental diets of the present study would reduce cost by approximately $17 \$ / t$. When locally produced, dietary incorporation of triticale would bring further environmental benefits, since less transportation will be needed.

Egg quality is recognised as an important variable in the food industry. It is determined by particular criteria reflecting morphological, chemical, physical and organoleptic aspects (Ledvinka et al., 2012). The results on egg production and quality are in agreement with published literature. Research by 
Karunajeewa (1978), Castanon et al. (1990), Çiftci et al. (2003) and Hermes and Johnson (2004) also found that triticale inclusion had no effect on albumen height and egg thickness but significantly decreased egg yolk colour intensity. Triticale has been reported to contain a low level of carotenoid (Karunajeewa, 1978; Castanon et al., 1990) resulting in paler yolks. Nevertheless, 5 to $20 \%$ of maize could be replaced with triticale in the diet without major incidence on egg quality.

The result on egg yolk fatty acid profile are in agreement with published reports (corroborate Karunajeewa and Tham, 1984; Shafey et al., 1992; Franco et al., 2020). Research by Karunajeewa and Tham (1984) found that triticale had no significant influence on yolk lipids except for palmitoleic acid (C16:1n-7). On the other hand, Shafey et al. (1992) found that triticale-based diets increased yolk linoleic acid (C18:2) concentration and decreased yolk oleic acid (C18:1) level. The higher inclusion of triticale in the previously mentioned trials (50 and $100 \%$ ) might be the cause of differences observed comparatively to our study ( 5 to $20 \%$ ). Our results showed that the replacement of maize by triticale inclusion of up to $20 \%$ in the diet had no significant influence on egg yolk fatty acids.

Blood plays a vital role in the physiological and nutritional status of animals and its inspection provides the opportunity to check the presence of metabolites and other constituents in the body (Etim et al., 2014b). Apart from the glucose level, the other blood biochemical variables remained unaffected by the presence of triticale at various levels. In a broiler study, Zarghi and Golian (2009) found similar results for triglyceride and cholesterol. The opposite to our findings, the same authors (Zarghi and Golian, 2009) suggested that the replacement of maize by various triticale levels $(25,50,75$ and $100 \%)$ did not influence glucose concentration in blood. Furthermore, Ebrahimi et al. (2017) noticed that different levels of triticale incorporation in the quail grower diet had a significant effect on the serum concentration of triglycerides. These diverse results might be attributed to the chemical composition variability among the triticale varieties used in those experiments. The specific metabolism of birds used in each experiment could also explain the differences between the results. While the effects of triticale on layers blood biochemical variables are not well understood due to a lack of investigations on this topic; nevertheless, we can suggest that replacement of maize by triticale at the level of $20 \%$ in layers diets will not have a detrimental impact on blood biochemical variables.

\section{Conclusions}

In conclusion, the replacement of maize with up to $20 \%$ triticale in laying hen diets did not impact the productive performance of the birds throughout the entire study. Triticale had no significant effect on the main egg quality variables but significantly decreased egg yolk colour intensity. The egg yolk fatty acid content and the majority of blood chemical constituents remained unaffected by the diets containing triticale. Only glucose concentration in the blood was significantly higher for hens fed diets containing a higher inclusion of triticale. Thus, it can be concluded that $20 \%$ replacement of maize with triticale in laying hen diets did not have any detrimental impact on egg production variables or the efficiency of production. However, further research involving higher dietary inclusion rates of triticale in laying hens diets is warranted.

\section{Acknowledgments}

This work was supported by the Agriculture, Food and Rural Affairs Convergence Technologies Program for Educating Global Creative Leaders, administered by the Korea Institute of Planning and Evaluation for Technology in Food, Agriculture, and Forestry (IPET) and funded by the Ministry of Agriculture, Food and Rural Affairs (MAFRA; 716002-7).

\section{Conflict of interest}

The authors declare that there is no conflict of interest.

\section{References}

Agro-Market24, 2021. International Agricultural Exchange. https:// agro-market24.eu/cereals-maize-price-buy-sell-88 (accessed on 05.11.202)

Bakhtiyary Moez N., Mirzaie Goudarzi S., Saki A.A., Ahmadi A., 2020. Effect of ground or whole wheat and triticale on productive performance, egg quality, gastrointestinal tract traits and nutrient digestibility of laying Japanese quails. Iran. J. Appl. Anim. Sci. 10, 355-363

Bielski S., Dubis B., Budzynski W., 2015. Influence of nitrogen fertilisation on the technological value of semi-dwarf grain winter triticale varieties Alekto and Gniewko. Pol. J. Nat. Sci. 30, 325-336

Boros D., 1999. Influence of $\mathrm{R}$ genome on the nutritional value of triticale for broiler chicks. Anim. Feed Sci. Technol. 76, 219-226, https://doi.org/10.1016/S0377-8401(98)00226-0

Castanon J.I.R., Ortiz V., Perez-Lanzac J., 1990. Effect of high inclusion levels of triticale in diets for laying hens containing $30 \%$ field beans. Anim. Feed Sci. Technol. 31, 349-353, https://doi. org/10.1016/0377-8401(90)90138-X 
Çiftci I., Yenice E., Eleroglu H., 2003. Use of triticale alone and in combination with wheat or maize: effects of diet type and enzyme supplementation on hen performance, egg quality, organ weights, intestinal viscosity and digestive system characteristics. Anim. Feed Sci. Technol. 105, 149-161, https://doi. org/10.1016/S0377-8401(03)00010-5

Cornejo S., Potocnjak J., Holmes J.H.G., Robinson D.W., 1973. Comparative nutritional value of triticale for swine. J. Anim. Sci. 36, 87-89, https://doi.org/10.2527/jas1973.36187x

Ebrahimi E., Sobhani Rad S., Zarghi H., 2017. Effect of triticale level and exogenous enzyme in the grower diet on performance, gastrointestinal tract relative weight, jejunal morphology and blood lipids of Japanese quail (Coturnix coturnix japonica). J. Agric. Sci. Technol. 19, 569-580, http://jast.modares.ac.ir/ article-23-2378-en.html

Etim N.A.N., Akpabio U., Okpongete R.O., Offiong E.E., 2014a. Do diets affect haematological parameters of poultry? $\mathrm{Br}$. J. Appl. Sci. Technol. 4, 1952-1965, https://doi.org/10.9734/ BJAST/2014/8900

Etim N.A.N., Williams M.E., Akpabio U., Offiong E.E.A., 2014b. Haematological parameters and factors affecting their values. Agric. Sci. 2, 37-47, https://doi.org/10.12735/as.v2i1p37

Fernandez R., Kim S.M., Buenrostro J.L., McGinnis J., 1973. Triticale and rye as main ingredients in diets for laying hens. Poult. Sci. 52, 2244-2252, https://doi.org/10.3382/ps.0522244

Franco D., Rois D., Arias A., Justo J.R., Marti-Quijal F.J., Khubber S., Barba F.J., López-Pedrouso M., Lorenzo J.M., 2020. Effect of breed and diet type on the freshness and quality of the eggs: a comparison between Mos (indigenous Galician breed) and Isa Brown hens. Foods 9, 342, https://doi.org/10.3390/ foods 9030342

Hassouna E.M.A., 2001. Some anatomical and morphometrical studies on the intestinal tract of chicken, duck, goose, turkey, pigeon dove, quail, sparrow, heron, jackdaw, hoopoe, kestrel and owl. Assiut Vet. Med. J. 44, 47-78, https://doi.org/10.21608/ avmj.2001.179299

Hermes J.C., Johnson R.C., 2004. Effects of feeding various levels of triticale var. Bogo in the diet of broiler and layer chickens. J. Appl. Poult. Res. 13, 667-672, https://doi.org/10.1093/ japr/13.4.667

Jamroz D., Skorupinska J., Orda J., Wiliczkiewicz A., Klünter A.-M., 2001. Use of wheat, barley or triticale in feed for laying hens supplemented with carbohydrases derived from Trichoderma Iongibrachiatum. J. Appl. Anim. Res. 19, 107-116, https://doi. org/10.1080/09712119.2001.9706714

Karunajeewa $H_{\text {., }}$ 1978. Effect of triticale, lucerne pellets, furazolidone, ethoxyquin and oxycarotenoids on egg yolk colour and performance of crossbred layers. Aust. J. Exp. Agric. Anim. Husb. 18, 396-403, https://doi.org/10.1071/EA9780396
Karunajeewa H., Tham S.H., 1984. The replacement value of triticale for barley in layer diets with or without rice pollard. J. Sci. Food Agric. 35, 970-976, https://doi.org/10.1002/jsfa.2740350904

Kelly L.M., Alworth L.C., 2013. Techniques for collecting blood from the domestic chicken. Lab Anim. 42, 359-361, https://doi. org/10.1038/laban.394

Ledvinka Z., Zita L., Klesalová L., 2012. Egg quality and some factors influencing it: a review. Sci. Agric. Bohem 43, 46-52

Leeson S., Summers J.D., 1987. Response of White Leghorns to diets containing ground or whole triticale. Can. J. Anim. Sci. 67, 583-585, https://doi.org/10.4141/cjas87-060

McNab J.M., Shannon D.W.F., 1975. The nutritive value of triticale and rye for the laying hen. Br. Poult. Sci. 16, 9-15, https://doi. org/10.1080/00071667508416153

Pirgozliev V., Bedford M.R., Acamovic T., 2010. Effect of dietary xylanase on energy, amino acid and mineral metabolism, and egg production and quality in laying hens. Br. Poult. Sci. 51, 639-647, https://doi.org/10.1080/00071668.2010.514325

Rao D.R., Johnson W.M., Sunki G.R., 1976. Replacement of maize by triticale in broiler diets. Br. Poult. Sci. 17, 269-274, https://doi. org/10.1080/00071667608416276

Reddy N.V., Rao D.R., Sunki G.R., 1979. Comparison of maize, wheat and triticale in broiler diets. Br. Poult. Sci. 20, 357-362, https:// doi.org/10.1080/00071667908416593

Shafey T.M., Dingle J.G., McDonald M.W., 1992. Comparison between wheat, triticale, rye, soyabean oil and strain of laying bird on the production, and cholesterol and fatty acid contents of eggs. Br. Poult. Sci. 33, 339-346, https://doi. org/10.1080/00071669208417472

Spring P., 2013. The challenge of cost effective poultry and animal nutrition: Optimizing existing and applying novel concepts. Lohmann Inf. 48, 38-46, https://www.lohmann-information. com/content/li_48_artikel5.pdf

Watts E.S., Rose S.P., Mackenzie A.M., Pirgozliev V.R., 2021. Investigations into the chemical composition and nutritional value of single-cultivar rapeseed meals for broiler chickens. Arch. Anim. Nutr. 75, 209-221, https://doi.org/10.1080/174503 9X.2021.1930455

Whiting I.M., Rose S.P., Mackenzie A.M., Amerah A.M., Pirgozliev V.R., 2019. Effect of wheat distillers dried grains with solubles and exogenous xylanase on laying hen performance and egg quality. Poult. Sci. 98, 3756-3762, https://doi.org/10.3382/ps/ pez063

Zarghi H., Golian A., 2009. Effect of triticale replacement and enzyme supplementation on performance and blood chemistry of broiler chickens. J. Anim. Vet. Adv. 8, 1316-1321, https://profdoc.um.ac.ir/paper-abstract-1012177.html 